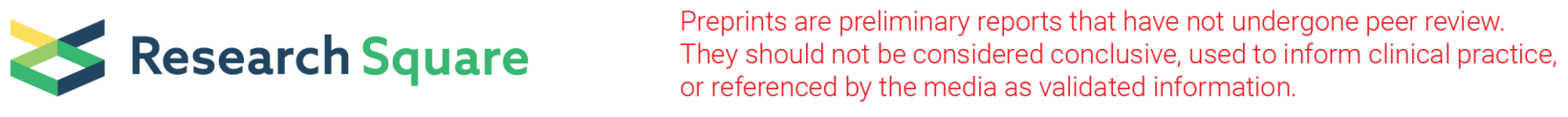

\title{
Prevalence and Radiographic Characteristics of Non-syndromic Supernumerary Teeth in a Shanghai Dental Hospital Pediatric Population: A Cross-sectional Study
}

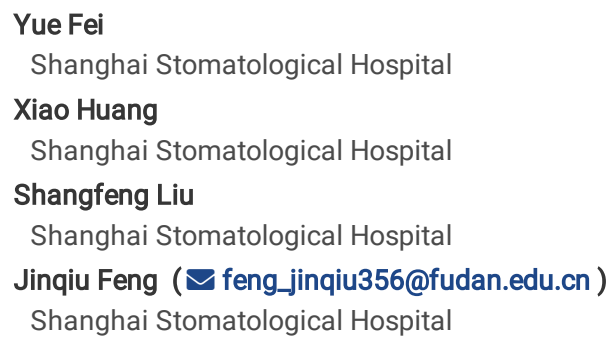

Keywords: Chinese children, non-syndromic Supernumerary teeth, Epidemiological data, Radiographic characteristics

Posted Date: September 15th, 2021

DOI: https://doi.org/10.21203/rs.3.rs-861833/v1

License: () (1) This work is licensed under a Creative Commons Attribution 4.0 International License. Read Full License 


\section{Abstract}

\section{Background}

Epidemiological studies can promote the further understanding of the characteristics of non-syndromic supernumerary teeth(ST) and provide references for the clinical work and the basic research in the future. This study aimed to investigate the prevalence and radiographic characteristics of non-syndrome supernumerary teeth (ST) in pediatric patients attending one Shanghai hospital.

\section{Methods}

Cone beam computed tomography (CBCT) of 639 subjects diagnosed with non-syndromic ST among 255259 pediatric patients visiting Shanghai Stomatology Hospital were analyzed to evaluate the number, morphology, location, orientation and sagittal position of supernumerary teeth. The profile of patients and radiographic characteristics were collected. Pearson's Chi-square test and Fisher exact test were employed to estimate the potential relationships between categorical covariates.

\section{Results}

The overall prevalence of ST was $0.25 \%$, and the male: female ratio was 3.07:1. Most ST were single, with a conical shape and vertical orientation, located in maxillary anterior region, palatally/lingually positioned in sagittal plain and detected in mixed dentition. Malposition of adjacent permanent teeth was most common complication. The morphology of ST was significantly correlated with development and eruption of the adjacent permanent teeth, while the orientation was only associated with malposition of neighboring teeth.

\section{Conclusions}

The epidemiological and radiographic data in this study can be applied as a reference for characterization understanding and clinical treatment planning of ST in Shanghai children and adolescents.

\section{Background}

The detection rate of supernumerary teeth (ST) is increasing with the improvement of oral health awareness. ${ }^{1}$ Genetic and environmental factors are believed to contribute to both non-syndromic and syndromic cases. ${ }^{2-4}$ For sporadic cases, evidences have been accumulating that signaling pathways including Wnt, FGF, BMP, and Shh are involved. While in syndromic patients, nearly 20 known syndromes are reported to be associated with ST, and the corresponding pathogenic genes are clarified. ${ }^{3,5}$ The popularity of the relevant etiological studies remains due to the application prospects in regenerative medicine. Since ST are usually extracted and discarded, they might become a valuable stem cell source with minimal ethical issues, play an important role in targeted molecular therapy for treatment of immune diseases, the regeneration of dentine-pulp complex and even the whole tooth regeneration. ${ }^{6-11}$

However, the exact molecular mechanism of ST formation is still unclear. ${ }^{1,3}$ Attention are therefore shifted to epidemiological studies for its promotion to clinical practice. The early detection of ST can be imperative in preventing the development of severe malocclusion, ${ }^{12,13}$ including the hindered eruption, rotation, malalignment, and root resorption of adjacent teeth. ${ }^{13,16}$ For the syndrome-related patients, the tooth anomalies occur earlier than other symptoms, making ST an important clue for early diagnosis of the correlated distinctive disorders. ${ }^{2,4}$

The achievement of these goals depends on clinical studies with high-quality. Compared with the syndrome-related cases, sporadic cases with ST are relatively common clinically. The available radiographic techniques consist of panoramic or periapical films and cone-beam computed tomography (CBCT). Since CBCT provides more precise, visualized and adequate information regarding dental structures, this method has been routinely applied for diagnosis and treatment planning of ST, ${ }^{17,18}$ facilitating the data collection of relevant clinical studies.

Literature from China, Brazil, India, Israel, Nigeria, Turkey, Spain, and Switzerland presented impressive data. ${ }^{12,13,19-34}$ The reported prevalence was 0.2-0.8\% in primary dentition and $0.15-5.3 \%$ in permanent dentition, ${ }^{1,12-16,19,21,22,31-33,35,36}$ mostly with a slight male preponderance. ${ }^{14-17,27,31-33,37,38}$ Noticeably, the occurrence was higher in Mongoloid racial group among Asian populations. 1,12,13,26,37 However, variations in studies among populations were found probably due to factors including ethnicity, sampling method, sample size, age distribution, diagnostic tools. ${ }^{12}$

Concerning prevalence of ST in Chinese children, there were several reports conducted in Beijing, Nanjing, Hong Kong and Taiwan. ${ }^{18,39-42}$ Since discrepancies in dental development among different ethnic groups in China, this may imply a need for large scale study on children and adolescents in Shanghai.

This study aimed to delineate the prevalence and radiographic characteristics of non-syndromic ST in pediatric patients attending one Shanghai hospital.

\section{Methods}

\section{Sample in this study}

With the approval from the Medical Ethics Committee in Shanghai Stomatology Hospital, Fudan University (2020[010]), this descriptive cross-sectional study was performed on children and adolescents born in Shanghai with diagnosis of ST among pediatric patients aged bellow 15 years old, which attending the hospital from October 2017 to October 2020. Subjects with images incomplete records and/or radiographs, with large-scale artifacts or unclear morphological 
features, a history of trauma, tooth agenesis, and medical conditions and syndromes known to be associated with supernumerary teeth were excluded from the analysis.

\section{Imaging protocols}

Radiological investigation was performed with a CBCT scanner (eXam Vision, Imaging Sciences International, Germany) by using the following settings: 6 cm x $32 \mathrm{~cm}$ field of view (FOV), $120 \mathrm{kV}, 5 \mathrm{~mA}, 14.7$ seconds exposure time and $0.279 \mathrm{~mm}$ slice thickness.

\section{Study variables}

Data collected included profile of patients (chronological age, sex, dentition), radiographic characteristics, and complications (e.g., rotation, impaction,

malposition of adjacent teeth, and "no effect") of ST.

Detailed characteristics of ST were listed below:

1. Number: single, multiple (two, three, four);

2. Location in the arch: maxilla/mandibular, mesiodens, lateral incisors, canine, premolar, paramolar and distomolar;

3. Morphology: supplemental ST refers to near duplicates of normal teeth, conical ST is a small peg-shape tooth, tuberculate ST have more than one cusp or tubercle and are frequently described as barrel-shaped, and odontoma refers to any lesion of odontogenic origin; ${ }^{13}$

4. Orientation: vertical, inverted, and transverse;

5. Sagittal position: labial/buccal, palatal/lingual.

\section{Statistical analysis}

To report the number and percentage of ST, relative frequency, mean, and standard deviation were used. Potential relationships between categorical covariates were evaluated by Pearson's Chi-square test or Fisher exact test. Cohen's weighted Kappa statistics with $95 \%$ confidence interval was conducted to estimate intra-observer reliability.

SPSS 24.0 software was used for all statistical analyses. The significance level was defined at a $P$ value less than 0.05 .

\section{Results}

\section{Intra-observer reliability}

The Kappa values regarding measurements of morphology, location, position and orientation of ST varied from 0.78 to 0.86 , indicating a substantial level of concordance.

\section{Epidemiological characteristics of patients with ST}

Among 25,5259 pediatric patients during the screening, 639 patients (486 males and 153) were found with 827 ST, showing a gender ratio of $3.18: 1$. The overall prevalence was $0.25 \%$. The prevalence of males and females was $0.55 \%$ and $0.21 \%$ respectively $\left(X^{2}=112.00, P<0.001\right)$. The mean age at the time of diagnosis was $7.27 \pm 0.83$ years, with a minimum of 3.1 years and a maximum of 14.7 years.

ST were most likely to be detected in mixed dentition (79.25\%), then followed by primary dentition (16.73\%) and permanent dentition (4.02\%).

\section{Radiographic characteristics of ST}

The representative images of 4 ST in one patient is presented in Fig. 1, and Fig. 2(a)-(d) shows the characteristics of ST regrading number, morphology, orientation and sagittal location. 457 (72.8\%) samples had a single ST, 179 (26.8\%) had two ST and only three child exhibited 4 ST (0.4\%). The most common morphology was conical type (70.9\%), followed by tuberculate type (18.0\%), supplemental form was reported in about only $8.1 \%$ of the sample. Vertical orientation was the most frequently reported (432, 52.3\%), 249 (29.7\%) ST were inverted oriented, and 149 (18.0\%) were transversely oriented. 647 (78.2\%) ST were palatally/lingually located, while $180(21.8 \%)$ ST were located in the buccal areas.

Regarding the location in the arch (Table 1), the majority of ST were located in the maxilla $(812,98.2 \%)$, among which 777 were mesiodens (94.0\%). Unlike those in the maxilla, ST in the mandible showed a higher incidence in the premolar area. 
Table 1

Descriptive characteristics of location of supernumerary teeth

\begin{tabular}{|lllll|}
\hline Characteristics & & N & $\%$ \\
\hline Location & Maxilla & mesiodens & 777 & 94.0 \\
\cline { 2 - 4 } & & lateral incisors & 25 & 3.0 \\
\cline { 2 - 4 } & premolars & 10 & 1.2 \\
Mandible & central incisors & 1 & 0.1 \\
\hline & canines & 1 & 0.1 \\
\hline & premolars & 13 & 1.6 \\
\hline
\end{tabular}

\section{Distribution of ST-related complications}

In this study, $180(28.17 \%)$ of the 639 children exhibited complications in the dentition. Malposition in adjacent permanent teeth was most commonly detected (17.3\%), followed by impaction (6.9\%) and rotation (4.0\%) of adjacent teeth.

The potential correlations between complications and morphology, orientation of ST are presented in Table 2. The statistical results demonstrated that the morphology of ST was significantly correlated to the occurrence of neighboring teeth impaction, rotation and malposition. Among all the shape, the tuberculate type was most associated with rotation (9.3\%) and malposition (32.2\%), while the odontoma form was most frequently correlated to impaction (29.4\%). Considering the orientation of ST, this factor was only significantly associated with the prevalence of malposition. ST transversely positioned caused malposition of adjacent teeth (28.9\%) more other than that were in vertical and inverted position.

Table 2

Relationship between complications and morphology, orientation of supernumerary teeth

\begin{tabular}{|c|c|c|c|c|c|c|c|c|c|}
\hline & \multicolumn{2}{|c|}{ Impaction of adjacent teeth } & \multirow[t]{2}{*}{$P$ value } & \multicolumn{2}{|c|}{ Rotation of adjacent teeth } & \multirow[t]{2}{*}{$P$ value } & \multicolumn{2}{|c|}{ Malposition of adjacent teeth } & \multirow[t]{2}{*}{$P$ value } \\
\hline & Yes & No & & Yes & No & & Yes & No & \\
\hline & 57 & 770 & & 33 & 794 & & 143 & 684 & \\
\hline Morphology & & & $\triangle 0.001 *$ & & & $0.003^{*}$ & & & $\triangle 0.001 *$ \\
\hline Conical & 33 & 554 & & 19 & 568 & & 95 & 492 & \\
\hline Tuberculate & 19 & 130 & & 14 & 135 & & 48 & 101 & \\
\hline Supplemental & 0 & 74 & & 0 & 74 & & 0 & 74 & \\
\hline Odontoma & 5 & 12 & & 0 & 17 & & 0 & 17 & \\
\hline Orientation & & & 0.342 & & & 0.814 & & & $\not 0.001 *$ \\
\hline Vertical & 33 & 399 & & 19 & 413 & & 67 & 365 & \\
\hline Inverted & 12 & 234 & & 9 & 237 & & 33 & 213 & \\
\hline Transverse & 10 & 139 & & 5 & 144 & & 43 & 106 & \\
\hline
\end{tabular}

\section{Discussions}

ST are relatively common developmental anomalies encountered in pediatric dentistry. ${ }^{27}$ Epidemiological studies on different populations can promote the further understanding of the characteristics of the ST and provide references for the clinical work and the basic research of ST in the future.

\section{Epidemiological information}

Unlike the higher prevalence reported in other Asian populations and Chinese children, ${ }^{13,18,39,40}$ the overall prevalence of this sample was similar with the result of $0.3 \%$ in the previous study on Turkish population. ${ }^{43}$ One possible attributing factor may be the sampling methodological differences. As subjects of most studies were patients but not randomly selected ordinary people, the results of prevalence were not based on the strict rule of epidemiological investigation owing to the ethical reason. Generally, there were two methods used to calculate the prevalence of ST. One was to detect persons diagnosed as having ST among patients who had taken radiographs, the other was to find persons with ST among all the studied patients whether having radiographs or not. This suggested that the prevalence of ST would probably not reflect the real conditions. They may incline to the high side when all the subjects took radiographs because of some clinical needs, and incline to the low side when only part of the subjects took radiographs. Our study may belong to the latter. Nevertheless, the prevalence of ST in this study can provide useful additional epidemiological information due to its large-sized sample and wide range of age groups. 
The significantly higher occurrence of ST in males was observed in this study, which is in accordance with most previous researches. ${ }^{18,21,27,28,31-33}$ However, few investigations reported a female preponderance or no difference in the ratio between sexes. ${ }^{12,13,21}$ The conflicting reports are possibly due to factors such as sampling method and ethnicity. The findings of male predilection may support that genetics play a role in the formation of ST. ${ }^{33,38}$

In accordance with published reports, ST was more frequently detected in mixed dentition. ${ }^{12,18,39,41}$ However, this may be probably more a reflection of diagnosis time rather than the real difference in developmental time. ${ }^{18,41}$

\section{Comparisons in characteristics of ST with previous reports}

Population differences in characteristics of ST have been demonstrated in different regions and ethnicities. ${ }^{44}$ Chinese population and cross-population comparisons of characteristics are presented in Table 3. Considering that secular trend may lead to bias in results, the comparisons only included the data from studies after 2000. If there were multiple reports on the same country, the most recent research was selected.

Table 3

Comparisons with previous studies

\begin{tabular}{|c|c|c|c|c|c|c|c|c|c|c|c|}
\hline \multirow[t]{2}{*}{ Author } & \multirow{2}{*}{$\begin{array}{l}\text { Region/ } \\
\text { Country }\end{array}$} & \multirow[t]{2}{*}{$\mathbf{N}$} & \multirow{2}{*}{$\begin{array}{l}\text { Age } \\
\text { range }\end{array}$} & \multirow{2}{*}{$\begin{array}{l}\text { Prevalence } \\
\text { (\%) }\end{array}$} & \multirow{2}{*}{$\begin{array}{l}\text { Sex } \\
\text { ratio }\end{array}$} & \multicolumn{6}{|c|}{ Characteristics } \\
\hline & & & & & & Number & Location & & Morphology & $\begin{array}{l}\text { Sagittal } \\
\text { position }\end{array}$ & Orientatic \\
\hline $\mathrm{Ma}^{18}$ & Nanjing & 18861 & $6-17$ & 10.52 & $1.86: 1$ & single & $\begin{array}{l}\text { maxillary } \\
\text { anterior }\end{array}$ & $\begin{array}{l}\text { mandibular } \\
\text { premolar }\end{array}$ & conical & $\begin{array}{l}\text { palatal/ } \\
\text { lingual }\end{array}$ & inverted $^{\mathrm{a}}$ \\
\hline Jiang $^{39}$ & Nanjing & 60104 & $\begin{array}{l}18- \\
87\end{array}$ & 1.5 & $1.76: 1$ & single & $\begin{array}{l}\text { maxillary } \\
\text { anterior }\end{array}$ & $\begin{array}{l}\text { mandibular } \\
\text { premolar }\end{array}$ & conical & $\begin{array}{l}\text { palatal/ } \\
\text { lingual }\end{array}$ & inverted $^{\mathrm{a}}$ \\
\hline Chou $^{40}$ & Taiwan & 6428 & $\begin{array}{l}0.6- \\
76\end{array}$ & 2.6 & $1.69: 1$ & single & $\begin{array}{l}\text { maxillary } \\
\text { anterior }\end{array}$ & $\begin{array}{l}\text { mandibular } \\
\text { premolar }\end{array}$ & conical & $\begin{array}{l}\text { palatal/ } \\
\text { lingual }\end{array}$ & vertical \\
\hline Anthonappa ${ }^{45}$ & $\begin{array}{l}\text { Hong } \\
\text { Kong }\end{array}$ & 382 & $2-16$ & - & $3.08: 1$ & single & $\begin{array}{l}\text { maxillary } \\
\text { anterior }\end{array}$ & - & conical & $\begin{array}{l}\text { Palatal/ } \\
\text { lingual }\end{array}$ & inverted $^{\mathrm{a}}$ \\
\hline Bereket $^{21}$ & Turkey & 111293 & $4-76$ & 0.76 & - & single & $\begin{array}{l}\text { maxillary } \\
\text { anterior }\end{array}$ & dismolar ${ }^{a}$ & conical & - & vertical \\
\hline Küchler ${ }^{30}$ & Brazil & 1198 & $6-12$ & 2.3 & $1.45: 1$ & single & $\begin{array}{l}\text { maxillary } \\
\text { anterior }\end{array}$ & - & conical & - & - \\
\hline $\begin{array}{l}\text { Fernández } \\
\text { Montenegro }^{28}\end{array}$ & Spain & 36057 & $5-56$ & 0.49 & $1.4: 1$ & single & $\begin{array}{l}\text { maxillary } \\
\text { anterior }\end{array}$ & $\begin{array}{l}\text { mandibular } \\
\text { premolar }\end{array}$ & conical & $\begin{array}{l}\text { palatal/ } \\
\text { lingual }\end{array}$ & - \\
\hline Patchett ${ }^{29}$ & Australia & 159 & $4-14$ & - & - & single & $\begin{array}{l}\text { maxillary } \\
\text { anterior }\end{array}$ & - & conical & - & - \\
\hline Anegundi ${ }^{27}$ & India & 63569 & $3-14$ & 1.24 & $1.55: 1$ & single & $\begin{array}{l}\text { maxillary } \\
\text { anterior }\end{array}$ & $\begin{array}{l}\text { maxillary } \\
\text { posterior }^{\mathrm{a}}\end{array}$ & conical & - & vertical \\
\hline Hajmohammadi ${ }^{12}$ & Iran & 5000 & - & 1.06 & $0.83: 1$ & single & $\begin{array}{l}\text { maxillary } \\
\text { anterior }\end{array}$ & $\begin{array}{l}\text { mandibular } \\
\text { dismolar }^{a}\end{array}$ & - & - & - \\
\hline Burhan 31 & Syria & 2753 & $\begin{array}{l}12.2- \\
20.5\end{array}$ & 1.4 & $1.8: 1$ & single & $\begin{array}{l}\text { maxillary } \\
\text { anterior }\end{array}$ & premolar & conical & - & - \\
\hline Singh ${ }^{32}$ & Nepal & 2684 & $6-14$ & 1.6 & 1.3:1 & single & $\begin{array}{l}\text { maxillary } \\
\text { anterior }\end{array}$ & $\begin{array}{l}\text { maxillary } \\
\text { premolar }\end{array}$ & conical & - & - \\
\hline McBeain ${ }^{33}$ & USA & 767 & $4-51$ & - & $1.5: 1$ & single & $\begin{array}{l}\text { maxillary } \\
\text { anterior }\end{array}$ & $\begin{array}{l}\text { mandibular } \\
\text { premolar }\end{array}$ & - & - & - \\
\hline Finkelstein ${ }^{13}$ & Israel & 3000 & - & 1.2 & $1.57: 1$ & single & $\begin{array}{l}\text { maxillary } \\
\text { anterior }\end{array}$ & $\begin{array}{l}\text { mandibular } \\
\text { premolar }\end{array}$ & conical & - & vertical \\
\hline Bello ${ }^{34}$ & Nigeria & 3616 & $\begin{array}{l}12- \\
95\end{array}$ & 1.74 & $1: 1$ & single & - & - & supplemental ${ }^{a}$ & - & vertical \\
\hline
\end{tabular}

${ }^{\dagger}$ Difference from the results in this study.

In agreement with previous researches on Chinese, Spanish, Australian, Indian, Syrian, Nepalese and Israeli, most ST in this study were single in number, conical in shape, palatal/lingual in sagittal position, and located in maxillary anterior region. ${ }^{13,18,21,27-32,39-41}$ Mandibular premolar area was the second in common location, which was supported by studies on Spanish, American, Israeli and other Chinese provinces including Nanjing and Taiwan. ${ }^{13,18,28,33,39,40}$

Unlike the vertical orientation reported in this sample, most ST of Chinese population in Nanjing and Hong Kong were invertedly positioned in sagittal plain. ${ }^{18,39,41}$ Moreover, according to Bello, ${ }^{34}$ supplementary type was identified as the predominant shape in Nigerian population. The explanation for these 
disagreements may be the differences in the recruitment of subjects and ethnicity.

\section{Comparisons of associated complications}

The result, malposition of adjacent teeth being the most frequently observed complication, was echoed with findings on Chinese in Nanjing, Hong Kong and Syrian. ${ }^{18,31,41}$ However, Jiang ${ }^{39}$ and Bello ${ }^{34}$ found ST caused cystic lesion more commonly. We believe that this discrepancy might result from difference in age range of sample. The occurrence of cysts would increase as more elder subjects are recruited.

With regard to the potential correlation between complications and characteristics of ST, morphology was significantly associated with eruption of neighboring teeth. Similar findings were reported by Park and his coworkers, ${ }^{1}$ that tuberculated ST was more likely to cause rotation and malposition compared with a conical ST. On the contrary, Leland and Lygidakis documented that, instead of the odontoma form reported in this study, the tuberculate type was more commonly associated with retention of adjacent permanent teeth. ${ }^{14,46}$

Unlike no significant correlation between the orientation of ST and impaction of neighboring teeth in this Chinese sample, Finkelstein detected that ST vertically positioned caused eruption delay more often than those that were inverted in Israeli. ${ }^{13}$ Taking the ethnic differences into account, more in-depth and broader studies on specific ethnic groups in specific areas are needed to assess the detailed correlations.

\section{Supernumerary teeth derived stem cells}

Since ST are comparatively accessible and noninvasive sources of stem cells, Supernumerary teeth derived stem cells (SNTSCs) become a promising source of dental pulp stem cells (DPSCs). ${ }^{3}$ SNTSCs were reported to have similar cell characteristics as ordinary DPSCs, exhibit a superior cell proliferation rate and potential differentiation. ${ }^{3,7,9}$ However, SNTSCs showed disadvantages with respect to cell migration and integrity maintenance during storage. ${ }^{1,3}$ Several investigations have clarified its efficacy on the in vitro animal models. Makino et al. testified the immunomodulatory functions of SNTSCs on T-cells in human systemic lupus erythematosus model mice. ${ }^{6}$ According to Yao et al., injection of the supernumerary teeth-derived apical papillary stem cells to a mouse hepatic fibrosis model significantly reduced inflammatory infiltration, enhanced liver-associated gene expression, and finally relieved symptoms. ${ }^{7}$

However, systematic and detailed exploration at the cellular and molecular levels are needed to verify the safety, effectiveness, and repeatability before largescale clinical applications of SNSTSCs. ${ }^{7}$

\section{Conclusions}

This retrospective analysis had documented the prevalence, radiographic characteristics of non-syndromic ST in a Shanghai pediatric dental population. Most ST were single, with a conical shape and vertical orientation, located in maxillary anterior region, palatally/lingually positioned in sagittal plain. Malposition in adjacent permanent teeth was most common complication. The morphology of ST was significantly correlated with eruption of the adjacent permanent teeth, while the orientation was only associated with malposition of neighboring teeth. Our findings can be applied as a reference for characterization understanding and clinical treatment planning of ST in Shanghai children and adolescents.

\section{Declarations}

\section{Ethics approval and consent to participate}

This study has been approved by the Medical Ethics Committee in Shanghai Stomatology Hospital, Fudan University (2020[010]). Informed consent for participation in the study was obtained from participants' parent or guardian.

\section{Consent for publication}

Not applicable.

\section{Availability of data and materials}

The data generated and analysed during the current study are not publicly available due privacy restrictions but are available from the corresponding author on reasonable request.

\section{Competing interests}

The authors declare that they have no competing interests.

\section{Funding}

Not applicable.

\section{Author Contributions}

Yue Fei: acquisition, analysis and manuscript drafting, Xiao Huang: interpretation of data and manuscript drafting, Shangfeng Liu: conception of the study, manuscript editing, and final approval of manuscript, Jinqiu Feng: design of the study, manuscript editing, and final approval of manuscript. 
This project was supported by Shanghai Stomatological Hospital Talent Project (SSDC-2020-CR01).

\section{References}

1. Park SY, Jang HJ, Hwang DS, Kim YD, Shin SH, Kim UK, et al. Complications associated with specific characteristics of supernumerary teeth. Oral Surg Oral Med Oral Pathol Oral Radiol 2020;130:150-5. doi: 10.1016/j.0000.2020.03.002.

2. Lu X, Yu F, Liu J, Cai W, Zhao Y, Zhao S, et al. The epidemiology of supernumerary teeth and the associated molecular mechanism. Organogenesis 2017;13:71-82. doi: 10.1080/15476278.2017.1332554.

3. Lu X, Liu SF, Wang HH, Yu F, Liu JJ, Zhao YM, et al. A biological study of supernumerary teeth derived dental pulp stem cells based on RNA-seq analysis. Int Endod J 2019;52:819-28. doi: 10.1111/iej.13060.

4. Yu F, Cai W, Jiang B, Xu L, Liu S, Zhao S. A novel mutation of adenomatous polyposis coli (APC) gene results in the formation of supernumerary teeth. J Cell Mol Med 2018;22:152-62. doi: 10.1111/jcmm.13303.

5. Acikgoz A, Acikgoz G, Tunga U, Otan F. Characteristics and prevalence of non-syndrome multiple supernumerary teeth: a retrospective study. Dentomaxillofac Radiol 2006;35:185-90. doi: 10.1259/dmfr/21956432.

6. Makino Y, Yamaza H, Akiyama K, Ma L, Hoshino Y, Nonaka K, et al. Immune therapeutic potential of stem cells from human supernumerary teeth. J Dent Res 2013;92:609-15. doi: 10.1177/0022034513490732.

7. Yao J, Chen N, Wang X, Zhang L, Huo J, Chi Y, et al. Human Supernumerary Teeth-Derived Apical Papillary Stem Cells Possess Preferable Characteristics and Efficacy on Hepatic Fibrosis in Mice. Stem Cells Int 2020;2020:6489396. doi: 10.1155/2020/6489396.

8. Kim D, Kim J, Hyun H, Kim K, Roh S. A nanoscale ridge/groove pattern arrayed surface enhances adipogenic differentiation of human supernumerary tooth-derived dental pulp stem cells in vitro. Arch Oral Biol 2014;59:765-74. doi: 10.1016/j.archoralbio.2014.04.014.

9. Huang AH, Chen YK, Lin LM, Shieh TY, Chan AW. Isolation and characterization of dental pulp stem cells from a supernumerary tooth. J Oral Pathol Med 2008;37:571-4. doi: 10.1111/j.1600-0714.2008.00654.x.

10. Takahashi K, Kiso H, Murashima-Suginami A, Tokita Y, Sugai M, Tabata Y, et al. Development of tooth regenerative medicine strategies by controlling the number of teeth using targeted molecular therapy. Inflamm Regen 2020;40:21. doi: 10.1186/s41232-020-00130-x.

11. Kim YH, Lee JS, Seo EJ, Park JK, Yea K, Shin J, et al. Oncostatin M enhances osteogenic differentiation of dental pulp stem cells derived from supernumerary teeth. Biochem Biophys Res Commun 2020;529:169-74. doi: 10.1016/j.bbrc.2020.06.013.

12. Hajmohammadi E, Najirad S, Mikaeili H, Kamran A. Epidemiology of Supernumerary Teeth in 5000 Radiography Films: Investigation of Patients Referring to the Clinics of Ardabil in 2015-2020. Int J Dent 2021;2021:6669436. doi: 10.1155/2021/6669436.

13. Finkelstein T, Shapira Y, Pavlidi AM, Schonberger S, Blumer S, Sarne O, et al. Prevalence and Characteristics of Supernumerary Teeth in Israeli Orthodontic Patients. J Clin Pediatr Dent 2019;43:244-51. doi: 10.17796/1053-4625-43.4.4.

14. Leyland L, Batra P, Wong F, Llewelyn R. A retrospective evaluation of the eruption of impacted permanent incisors after extraction of supernumerary teeth. J Clin Pediatr Dent 2006;30:225-32. doi: 10.17796/jcpd.30.3.60p6533732v56827.

15. Syriac G, Joseph E, Rupesh S, Philip J, Cherian SA, Mathew J. Prevalence, Characteristics, and Complications of Supernumerary Teeth in Nonsyndromic Pediatric Population of South India: A Clinical and Radiographic Study. J Pharm Bioallied Sci 2017;9:S231-s6. doi: 10.4103/jpbs.JPBS_154_17.

16. Ferrés-Padró E, Prats-Armengol J, Ferrés-Amat E. A descriptive study of 113 unerupted supernumerary teeth in 79 pediatric patients in Barcelona. Med Oral Patol Oral Cir Bucal 2009;14:E146-52.

17. Gurler G, Delilbasi C, Delilbasi E. Investigation of impacted supernumerary teeth: a cone beam computed tomograph (cbct) study. J Istanb Univ Fac Dent 2017;51:18-24. doi: 10.17096/jiufd.20098.

18. Ma X, Jiang Y, Ge H, Yao Y, Wang Y, Mei Y, et al. Epidemiological, clinical, radiographic characterization of non-syndromic supernumerary teeth in Chinese children and adolescents. Oral Dis 2021;27:981-92. doi: 10.1111/odi.13628.

19. Sharma A, Singh VP. Supernumerary teeth in Indian children: a survey of 300 cases. Int J dentistry 2012;2012:745265. doi: 10.1155/2012/745265.

20. Celikoglu M, Kamak H, Oktay H. Prevalence and characteristics of supernumerary teeth in a non-syndrome Turkish population: associated pathologies and proposed treatment. Med Oral Patol Oral Cir Bucal 2010;15:e575-8. doi: 10.4317/medoral.15.e575.

21. Bereket C, Çakır-Özkan N, Şener I, Bulut E, Baştan A. Analyses of 1100 supernumerary teeth in a nonsyndromic Turkish population: A retrospective multicenter study. Niger J Clin Pract 2015;18:731-8. doi: 10.4103/1119-3077.154213.

22. Mossaz J, Kloukos D, Pandis N, Suter VG, Katsaros C, Bornstein MM. Morphologic characteristics, location, and associated complications of maxillary and mandibular supernumerary teeth as evaluated using cone beam computed tomography. Eur J Orthod 2014;36:708-18. doi: 10.1093/ejo/cjt101.

23. Tyrologou S, Koch G, Kurol J. Location, complications and treatment of mesiodentes-a retrospective study in children. Swed Dent J 2005;29:1-9.

24. Maddalone M, Rota E, Amosso E, Porcaro G, Mirabelli L. Evaluation of Surgical Options for Supernumerary Teeth in the Anterior Maxilla. Int J Clin Pediatr Dent 2018;11:294-8. doi: 10.5005/jp-journals-10005-1529.

25. Kang E, Choi N, Kim S. Three Dimensional Analysis of Maxillary Mesiodens Using Dental CBCT and Relationship Between the Mesiodens and Diastema. J Korean Acad Pediatr Dent 2013;40:260-7.

26. Leco Berrocal MI, Martín Morales JF, Martínez González JM. An observational study of the frequency of supernumerary teeth in a population of 2000 patients. Med Oral Patol Oral Cir Bucal 2007;12:E134-8.

27. Anegundi RT, Tegginmani VS, Battepati P, Tavargeri A, Patil S, Trasad V, et al. Prevalence and characteristics of supernumerary teeth in a non-syndromic South Indian pediatric population. J Indian Soc Pedod Prev Dent 2014;32:9-12. doi: 10.4103/0970-4388.127041.

Page 7/10 
28. Fernández Montenegro P, Valmaseda Castellón E, Berini Aytés L, Gay Escoda C. Retrospective study of 145 supernumerary teeth. Med Oral Patol Oral Cir Bucal 2006;11:E339-44.

29. Patchett CL, Crawford PJ, Cameron AC, Stephens CD. The management of supernumerary teeth in childhood-a retrospective study of practice in Bristol Dental Hospital, England and Westmead Dental Hospital, Sydney, Australia. Int J Paediatr Dent 2001;11:259-65. doi: 10.1046/j.1365-263x.2001.00282.x.

30. Küchler EC, Costa AG, Costa Mde C, Vieira AR, Granjeiro JM. Supernumerary teeth vary depending on gender. Braz Oral Res 2011;25:76-9. doi: 10.1590/s1806-83242011000100013.

31. Burhan AS, Nawaya FR, Arabi Katbi ME, Al-Jawabra AS. Prevalence of supernumerary teeth in a nonsyndromic Syrian sample. J Egypt Public Health Assoc 2015;90:146-9. doi: 10.1097/01.EPX.0000475614.20865.db.

32. Singh VP, Sharma A, Sharma S. Supernumerary teeth in Nepalese children. TheScientificWorldJournal 2014;2014:215396. doi: 10.1155/2014/215396.

33. McBeain M, Miloro M. Characteristics of Supernumerary Teeth in Nonsyndromic Population in an Urban Dental School Setting. J Oral Maxillofac Surg 2018;76:933-8. doi: 10.1016/j.joms.2017.10.013.

34. Bello S, Olatunbosun W, Adeoye J, Adebayo A, Ikimi N. Prevalence and presentation of hyperdontia in a non-syndromic, mixed Nigerian population. J Clin Exp Dent 2019;11:e930-e6. doi: 10.4317/jced.55767.

35. Shekhar MG. Characteristics of premaxillary supernumerary teeth in primary and mixed dentitions: a retrospective analysis of 212 cases. $\mathrm{J}$ Investig Clin Dent 2012;3:221-4. doi: 10.1111/j.2041-1626.2012.00118.x.

36. Patil S, Maheshwari S. Prevalence of impacted and supernumerary teeth in the North Indian population. J Clin Exp Dent 2014;6:e116-20. doi: $10.4317 /$ jced.51284.

37. Amarlal D, Muthu MS. Supernumerary teeth: review of literature and decision support system. Indian J Dent Res 2013;24:117-22. doi: 10.4103/09709290.114911.

38. Herath C, Jayawardena C, Nagarathne N, Perera K. Characteristics and sequelae of erupted supernumerary teeth: A study of 218 cases among Sri Lankan children. J Investig Clin Dent 2017;8. doi: 10.1111/jicd.12250.

39. Jiang Y, Ma X, Wu Y, Li J, Li Z, Wang Y, et al. Epidemiological, clinical, and 3-dimentional CBCT radiographic characterizations of supernumerary teeth in a non-syndromic adult population: a single-institutional study from 60,104 Chinese subjects. Clin Oral Investig 2020;24:4271-81. doi: 10.1007/s00784-02003288-3.

40. Chou S-T, Chang H-P, Yang Y-H, Lung C-Y, Tseng Y-C, Pan C-Y, et al. Characteristics of supernumerary teeth among nonsyndromic dental patients. J Dent Sci 2015;10:133-8.

41. Anthonappa RP, Omer RS, King NM. Characteristics of 283 supernumerary teeth in southern Chinese children. Oral Surg Oral Med Oral Pathol Oral Radio Endod 2008;105:e48-54. doi: 10.1016/j.tripleo.2008.01.035.

42. Liu JF. Characteristics of premaxillary supernumerary teeth: a survey of 112 cases. ASDC J Dent Child 1995;62:262-5.

43. Esenlik E, Sayin MO, Atilla AO, Ozen T, Altun C, Basak F. Supernumerary teeth in a Turkish population. Am J Orthod Dentofacial Orthop 2009;136:848-52. doi: 10.1016/j.ajodo.2007.10.055.

44. Ata-Ali F, Ata-Ali J, Penarrocha-Oltra D, Penarrocha-Diago M. Prevalence, etiology, diagnosis, treatment and complications of supernumerary teeth. J Clin Exp Dent 2014;6:e414-8. doi: 10.4317/jced.51499.

45. Anthonappa RP, King NM, Rabie ABM. Aetiology of supernumerary teeth: a literature review. Eur Arch Paediatr Dent 2013;14:279-88. doi: 10.1007/s40368-013-0082-z.

46. Lygidakis NN, Chatzidimitriou K, Theologie-Lygidakis N, Lygidakis NA. Evaluation of a treatment protocol for unerupted maxillary central incisors: retrospective clinical study of 46 children. Eur Arch Paediatr Dent 2015;16:153-64. doi: 10.1007/s40368-014-0150-z.

\section{Figures}


a

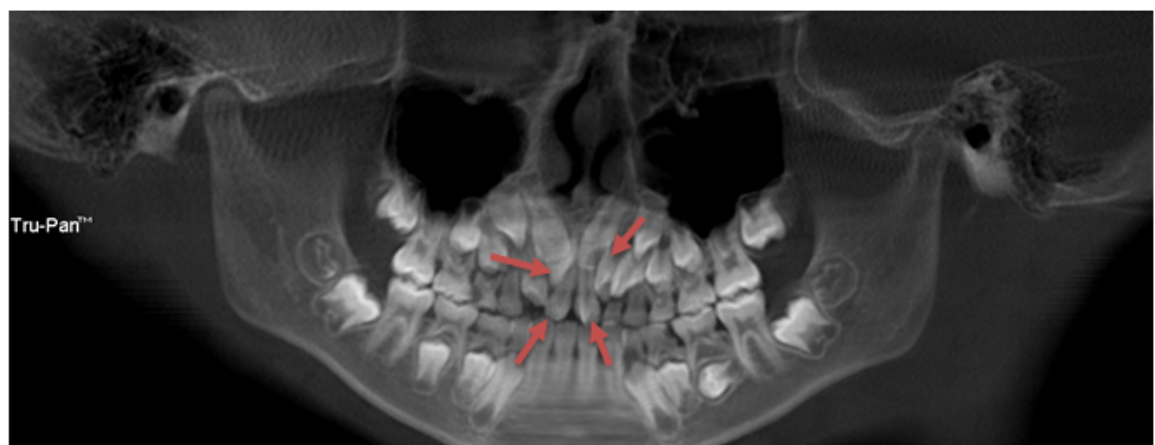

b

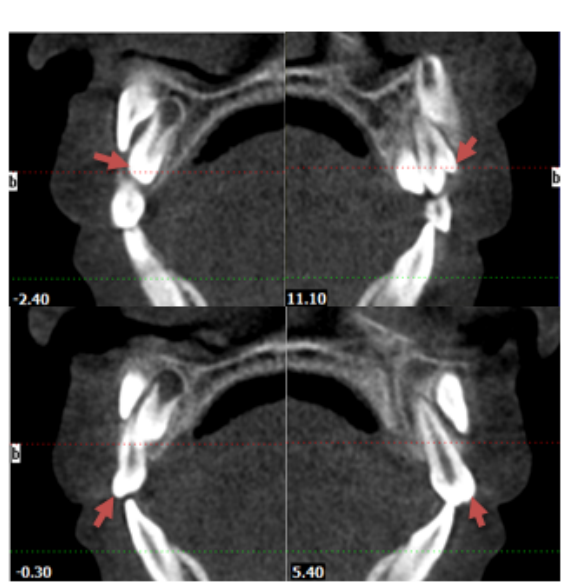

C

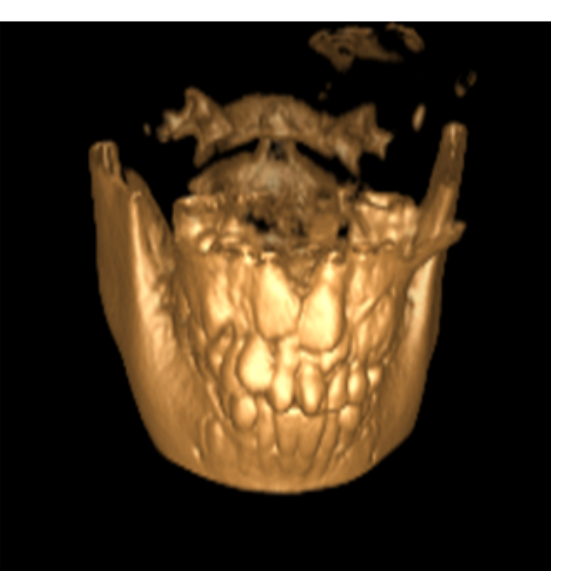

Figure 1

Representative CBCT images presenting 4 ST of a 9-year-old male patient. (a) Paronamic images using Tru-Pan function; (b). Sagittal plane images of 4 ST; (c) $3 \mathrm{D}$ reconstruction view of the dentition 
a

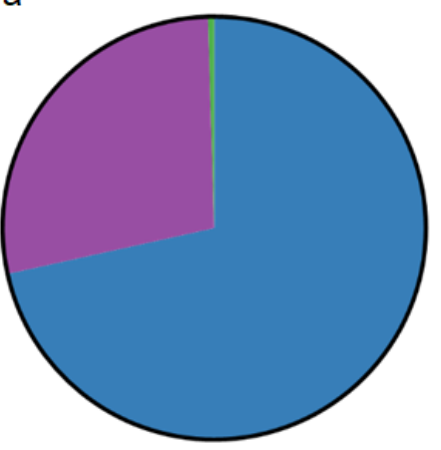

$$
\begin{aligned}
& \square \text { Single } \\
& \square \text { Double } \\
& \square \text { Tetrad }
\end{aligned}
$$

C
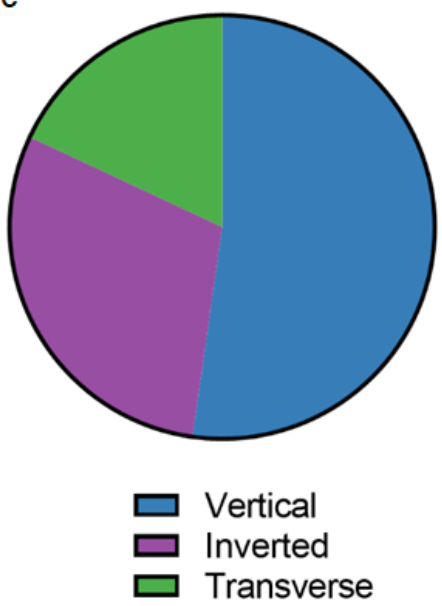

b

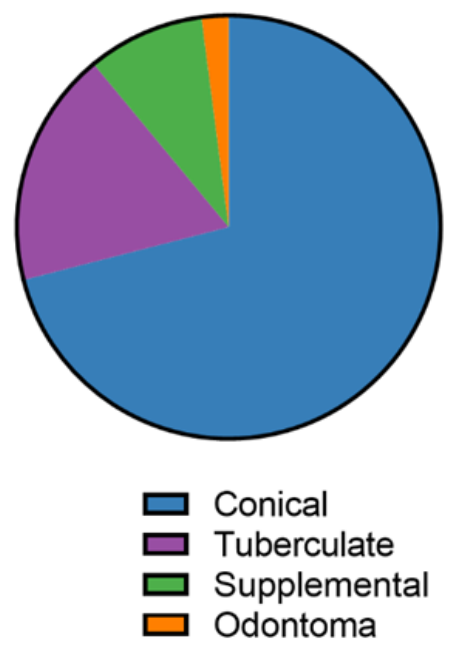

d

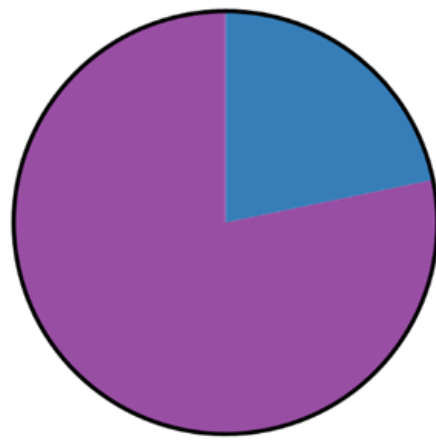

$\square$ Buccal/Labial
$\square$ Palatal/Lingual

Figure 2

Radiographic characteristics of ST. (a) Distribution of number of ST (b) Distribution of morphology of ST; (c) Distribution of orientation of ST; (d) Distribution of sagittal location of ST 